\title{
Relationship between Changes in Magnetic Flux Density Distribution around Fatigue Crack and Plastic Deformation around Crack Tip
}

\author{
学 ○島田 純 （滋賀県立大） 正 田邊 裕貴 (滋賀県立大) 正 高松 徹 （滋賀県立大） \\ 正和泉 遊以（滋賀県立大）正 木田 勝之（九州大） \\ Jun SHIMADA, University of Shiga Prefecture, Hassaka 2500, Hikone, Shiga 522-8533 \\ Hirotaka TANABE, University of Shiga Prefecture \\ Tohru TAKAMATSU, University of Shiga Prefecture \\ Yui IZUMI, University of Shiga Prefecture \\ Katsuyuki KIDA, Kyushu University
}

\section{1 緒 言}

これまでに筆者らは，磁場情報に基づく非破壊的疲労損 傷評価手法の開発を目的として, 疲労き裂進展過程におけ るき裂周辺の磁束密度分布の観察を実施し, き裂の進展に 伴いき裂周辺の磁束密度分布がき裂進展方向に移動するこ と, また, その移動量と応力拡大係数との間に相関関係が 存在することを示した ${ }^{1)}$. さらに, その磁束密度分布変化 のメカニズムに, 疲労き裂先端の塑性変形による磁区拘束 が関係している可能性を指摘した ${ }^{1)}$. 本研究では, この関 係を検証するために, き裂周辺における塑性変形の分布を 反映すると予想される X 線回折線半価幅 FWHM の分布を 測定し, き裂周辺部の磁束密度分布との対応関係を調べた.

\section{2 実験方法}

供試材には SCM440 鋼を用いた。試験片の寸法は長さ $125 \mathrm{~mm}$, 幅 $25 \mathrm{~mm}$, 厚さ $10 \mathrm{~mm}$ で, 中央部には長さ $2 \mathrm{~mm}$, 先端半径 $100 \mu \mathrm{m}$ の切欠きを放電加工により導入した. 4 点 曲げ疲労試験は, 油圧サーボ疲労試験機を用いて行った。 上記方法により疲労き裂を長さ $9 \mathrm{~mm}$ まで進展させた試験 片に対して，まず，き裂周辺の塑性変形による磁区拘束を 緩和するために焼きなましを行った，次に，焼きなまし後 に再度疲労試験を実施し, き裂を $1 \mathrm{~mm}$ 進展させ, き裂進 展部に再度, 塑性変形による磁区拘束を与えた。 これらの 過程での, 疲労き裂周辺の磁束密度分布の変化, ならびに き裂周辺に抢ける X 線回折線半価幅 FWHM の分布の変化 を測定した. 磁束密度分布測定にはMIセンサを使用した。 FWHM の測定には，X線回折装置 (マックサイエンス社製, M03XHF22）を用いた. 特性 X 線には $\mathrm{Cr}-\mathrm{K} \alpha$ 線を使用し, Fe211 回折線の FWHM を測定した. 管電圧は $30 \mathrm{kV}$, 管電 流は $30 \mathrm{~mA}$ とした. 測定は, 試験片表面の切欠き根元を $y=0$ とし，き裂進展線上に $y$ 軸をとったときの, $3 \mathrm{~mm} \leqq y \leqq 11 \mathrm{~mm}$ の範囲に対して $1 \mathrm{~mm}$ 間隔で実施した. 測定にあたっては, 測定部を限定するため, 直径 $1 \mathrm{~mm}$ の穴を空けた厚さ $0.25 \mathrm{~mm}$ の鉛板でマスキングした．測定はそれぞれの測定 位置に対して 3〜5 回ずつ実施した.

\section{3 実験結果および考察}

実験結果を図 1 に示寸. 図 1 の左側が FWHM, 右側が磁 束密度 $B_{x}$ の測定結果を示している. $B_{x}$ は試験片表面に平行 で切欠きと垂直な方向の磁束密度の成分を表している. FWHM 測定結果の図中の破線は, き裂から十分離れた試験 片端部での FWHM の值を表している.

疲労試験後の試験片に対して焼きなましを実施すると，
き裂周辺部の磁束密度は低下した，また，その磁束密度変 化と, き裂周辺部での FWHM の変化との間には対応関係 が認められた．さらに，焼きなまし後に再度疲労試験を実 施したところ，新たにき裂が進展した部分の周辺に磁束密 度の増加が認められた．また，その部分では，FWHMにも 増加傾向が認められ，両者の対応関係が確認された。

なお, 最大荷重や応力比の異なる条件下で疲労試験を実 施した複数の試験片に対して同様の検討を行ったところ, いずれも同様の結果が得られた。

以上より, 疲労き裂進展に伴うき裂㓮辺での磁束密度分 布の変化は, 塑性変形による磁区拘束を主要因とする変化 である可能性が高いと考えられた。

\section{参考文献}

1) H. Tanabe, et al., Elsevier, Procedia Engineering (ICM11), Vol.10, pp.881-886(2011).
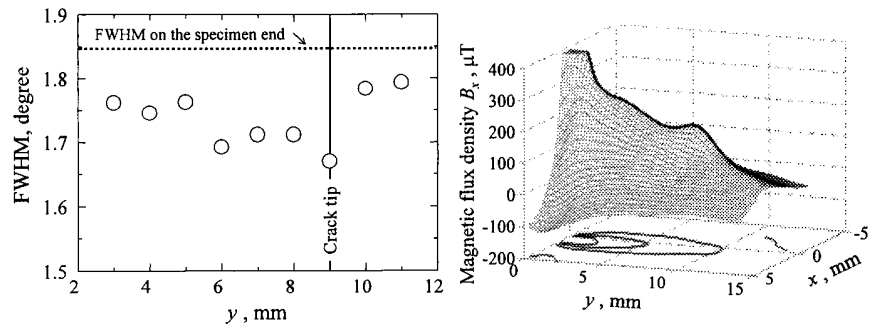

(a) Before annealing (After fatigue test)

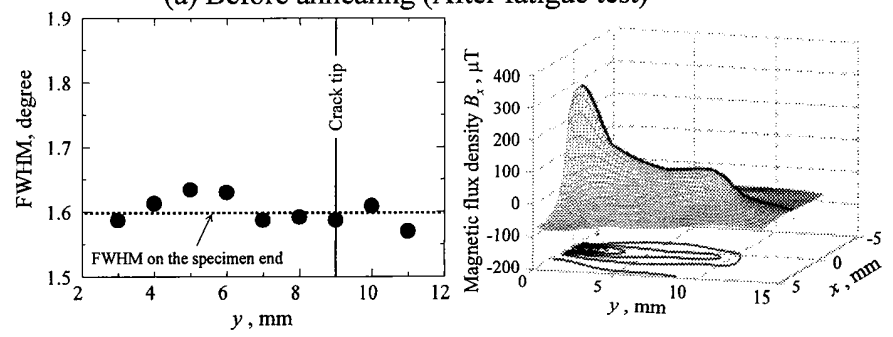

(b) After annealing



(c) After additional fatigue test

Fig.1 Relationship of FWHM and $B_{x}$ 